\title{
TARJUMĀN AL-MUSTAFĪD: TAFSIR LENGKAP PERTAMA DI NUSANTARA
}

\author{
Zaimul Asroor ${ }^{1}$ \\ ${ }^{1}$ Universitas Islam Negeri Syarif Hidayatullah Jakarta \\ Tangerang Selatan, Banten, Indonesia \\ asroraim7@gmail.com
}

\begin{abstract}
Abstrak:
Tulisan ini mendiskusikan karakteristik, dan metode tafsir Tarjumān alMustafid. Dengan menggunakan metode deskriptif-analitik, studi menjawab pertanyaan bagaimana corak tafsir Tarjumān al-Mustafìd karya 'Abd alRa'üf? Penulis menemukan bahwa meskipun pengarang tafsir ini pernah menjabat mufti saat pemerintahan Sulțānah Safiat al-Dīn Tāj al-'Alām (16411675), namun — sejauh pengamatan penulis-belum ditemukan pengaruh politis dalam kitab tafsirnya. Terlebih, meskipun 'Abd al-Ra'üf adalah seorang mursyīd tarekat Syattariyah, namun ia tidak banyak memberikan nuansa kesufian dalam tafsirnya. Ini sekaligus menolak beberapa anggapan bahwa tafsir Tarjumān al-Mustafíd bercorak kesufian.
\end{abstract}

Kata Kunci: 'Abd al-Ra'ūf, Tarjumān al-Mustafìd, Tafsir.

\section{Abstrack:}

This paper discusses the characteristics, and methods of interpretation of Tarjumān al-Mustafid. Using the descriptive-analytic method, the study answers the question of how are the characteristics of Tarjumān al-Mustafid, written by 'Abd al-Ra'üf? The writer finds that although the author of this tafsir had served as a mufti during the reign of the Sultānah Safiat al-Dīn Tāj al'Alām (1641-1675), but - as far as the writer could observe, no political influence was found in this book of commentary. Moreover, although 'Abd al$R \bar{a}$ 'uf was a mursyid of the Syattariyah tariqah, he did not give much nuance to his book of tafsir. At the same time, this finding rejects the assumption that Tarjumān al-Mustafid can be characterized to have sufi nuances in it.

Keywords: 'Abd al-Ra 'ūf, Tarjumān al-Mustafìd, interpretation. 


\section{Pendahuluan}

Bertebarannya kitab tafsir karya ulama Nusantara dari abad ke-17 sampai sekarang seolah menjadi bukti, bahwa para mufasir di negeri ini sadar akan pentingnya sebuah pemahaman kitab suci yang bisa menjadi pedoman bagi masyarakat Nusantara. Hal ini sangat wajar karena terdapat sebuah realita jika Indonesia merupakan negara yang memiliki masyarakat muslim dunia terbesar. Sehingga mau tidak mau, pemahaman yang tepat atas al-Qur'an menjadi sesuatu yang sangat penting. Dan itu tidak lain adalah dengan memahami penafsiran para ulama terhadapnya (al-Qur'an).

Proses penafsiran al-Qur'an di Indonesia tak secepat di negara-negara Timur Tengah semisal Arab Saudi, Mesir, dan lainnya. Hal ini tidak lain disebabkan karena meskipun Indonesia menjadi negara dengan mayoritas masyarakat muslim, namun bahasa ibu yang digunakan oleh masyarakat muslim Indonesia bukanlah bahasa Arab, melainkan bahasa Indonesia. ${ }^{1}$

Dari berbagai karya tafsir yang muncul di Indonesia, Tarjumān alMustafìd adalah salah satu pionirnya. Melalui karya tafsir Syaikh 'Abd al-Ra'ūf Singkel ini, banyak sekali akademisi maupun masyarakat secara umum yang mendapatkan manfaatnya.

\section{Latar Belakang Pendidikan dan Sosio-Politik \\ 'Abd al-Ra'ūf Singkel}

'Abd al-Ra'ūf Singkel dilahirkan di Singkel ${ }^{2}$ pada 1035 H/1615 M. ${ }^{3}$ Ia menghembuskan nafas terakhirnya di Banda Aceh pada 1105 H/1693 M. Nama aslinya adalah 'Abd al-Ra'ūf al-Fansuri. ${ }^{4}$ Bapaknya yakni Syaikh Ali. ${ }^{5}$

'Abd al-Ra'ūf memulai pendidikan pertamanya di desanya sendiri. Ayahnya merupakan tenaga pendidik yang merintis madrasah yang akhirnya sanggup membuat murid-murid dari beragam wilayah Aceh tertarik. Setelah

1 Nashruddin Baidan, Perkembangan Tafsir al-Qur'an di Indonesia (Solo: Tiga Serangkai Pustaka Mandiri, 2003), 31.

${ }^{2}$ Singkil (Singkel) menunjukkan wilayah pantai barat laut Aceh.

${ }^{3}$ Zulkefli Aini', Che Zarrina Sa'ari, dan Mohamad Zulkifli Abdul Ghani, "Pendekatan Dakwah al-Wasatiyyah Syeikh Abdul Rauf Ali al-Fansuri (M.1693)," Afkar 20, no. 1 (2018): 190.

${ }^{4}$ Sebagian masyarakat Indonesia mengenalnya dengan sebutan Syekh Kuala. Terkait kapan dan tempat kelahiran Syaikh 'Abd al-Ra'üf sendiri masih menjadi perdebatan di kalangan peneliti. Lihat Rizem Aizid, Biografi Ulama' Nusantara (Yogyakarta: Diva Press, 2016), 89.

${ }^{5}$ M. Sholihin, Melacak Pemikiran Tasawuf Dinusantara (Jakarta: PT Raja Grafindo Persada, 2005), 60 
belajar di kampung halamannya, ia melanjutkan pendidikannya di Fansur, sebuah daerah yang dikenal sebagai pusat keislaman. ${ }^{6}$

Kemudian, 'Abd al-Ra'ūf berangkat menuju $\mathrm{Arab}^{7}$ guna memperdalam ilmu agama, yakni sekitar tahun $1064 \mathrm{H} / 1643 \mathrm{M}$. Ia menyinggahi sentral pendidikan Islam di seluruh jalur perjalanan hajinya antara Yaman hingga Makkah. Selanjutnya, ia tinggal di Makkah serta Madinah guna menimba beberapa cabang ilmu agama. ${ }^{8}$ Ia menekuni tarekat Sattariyah Aḥmad al-Qușāṣi (1583-1661 M) serta Ibrāhīm al-Qurāni. Dari al-Qușașịi ia mempelajari perihal ilmu kebatinan, yakni tasawuf serta keilmuan yang berhubungan. Sebagai simbol penyelesaiannya dalam mempelajari ilmu mistis, al-Quṣașịi mengangkatnya menjadi khalifah Syattariyah serta Qadiriyah.

Sepanjang 'Abd al-Ra'ūf mengabdi pada al-Qușāși sebagai khalifah, gurunya pernah memberinya perintah untuk balik ke Jawa (panggilan untuk Indonesia masa itu), guna memberi bantuan dalam mengembangkan Islam di wilayah asalnya. Tapi, ia tak ingin kembali ketika itu sebab ia masih memiliki niat untuk memperdalam keilmuannya. Setelah ia menimba ilmu lebih banyak dari gurunya lalu gurunya wafat, setelah itu ia merasa cukup serta langsung pulang kampung. ${ }^{9}$

'Abd al-Ra'ūf kembali ke kampung halamannya kurang lebih pada 1662 M kemudian menyebarkan tarekat ini. ${ }^{10}$ Menurut Rinkes, kepulangannya bertepatan setelah gurunya yang bernama Ahmad al-Qușāși wafat pada tahun 1961. 'Abd al-Ra'ūf juga sekaligus mencatatkan namanya sebagai orang pertama yang mengembangkan ajaran tarekat Sattariyah di Indonesia. ${ }^{11}$ Ia

6 Akbarizan, Tasawuf Integratif Pemikiran dan Ajaran Tasawuf di Indonesia (Pekanbaru: Suska Press, 2008), 78.

7 'Abd al-Ra'ūf mencatat bahwa ia menghabiskan sekitar 19 tahun untuk belajar di Arabia. Lihat Azzyumardi Azra, The Origin of Islamic Reformism in SouthEast Asia (Network of Malay-Indonesian and Middle Eastern Ulama'in the Seventeenth and Eighteenth Century) (Australia: University of Hawai's Press, 2004), 77. Lihat juga Rasyad, Hermansyah, dan Zulkhairi, "Tanbih Al-Masyi Al-Mansub Ila Thariq Al-Qusyasyi: Analisis Uslub Bahasa Arab dalam Karya 'Abd Ar-Rauf As-Singkili sebagai Syaikh al-Islam dan Mufti Qadhi al-Adil di Kesultanan,” Adabiya 18, no. 35 (2016): 64.

${ }^{8}$ Di dalam kitabnya al-'Umdah, 'Abd al-Ra'ūf menceritakan tentang masa, lokasi belajar dan guru yang mengajarnya. Ia memang lebih banyak menghabiskan waktu belajarnya dalam mendalami ilmu-ilmu keislaman ketika di Madinah. Lihat Damanhuri, "Umdatul Muhtajin: Rujukan Tarekat Syattariah Nusantara," Ulumuna: Jurnal Studi Keislaman 17, no. 2 (2013).

${ }^{9}$ Damanhuri, “'Umdatul Muhtajin: Rujukan Tarekat Syattariah Nusantara,” 308.

${ }^{10}$ Taufiqurrahman, "Kajian Tafsir Indonesia," Jurnal Mutawâtir 2, no. 1 (2012): 9.

${ }^{11}$ M. Sholihin, Melacak Pemikiran Tasawuf di Nusantara, 60. Selain itu, 'Abd al-Ra'ūf juga berjasa dalam menempatkan posisinya sebagai ulama yang mangambil jalan tengah ketika terjadi pertentangan pemikiran antara Syeh Hamzah Fansyuri (penganut paham Wujudiyah) dan 
mendapatkan ijazah dari dua tarekat, Syattariyah serta Naqsyabandiyah. Akan tetapi ia tak serupa dengan kawannya Syaikh Yūsuf al-Makassari. Syaikh Yūsuf mengembangkan Naqsyabandiyah dan 'Abd al-Ra'ūf mengembangkan Syattariyah. Keputusannya memiliki alasan khusus yang bisa ditinjau di Pasal Pada Menyatakan Masyaikh Ahli al-Tariqah. 'Abd al-Ra'ūf di sini menyatakan secara langsung jika tarekat Syattariyah lebih gampang (untuk dijalani), lebih luhur (dari segi tingkatannya), amalan-amalannya bersumber dari Qur'an, hadis dan juga dipraktikkan oleh sahabat Nabi. ${ }^{12}$

Hubungan 'Abd al-Ra'ūf Singkel dengan kerajaan Aceh waktu itu juga bisa dibilang sangat bagus. Tidak heran bila sekembalinya dari Timur Tengah ia kemudian diangkat menjadi mufti kerajaan Aceh ketika era Sulțānah Safiat alDīn Tāj al-'Alām (1641-1675), anak perempuan dari Iskandar Muda dan janda dari Iskandar Tsani. Pengangkatan 'Abd al-Ra'ūf sebagai mufti ini bersamaan dengan wafatnya Syaikh Saif al-Rijal yang tahun 1661 M. Ia dilantik menjadi Syaikh Jamī'ah al-Rahmān atau mufti kerajaan hingga wafat. ${ }^{13}$ Di masa awal kembalinya ke Aceh ini pula, 'Abd al-Ra'ūf diminta Sultānah untuk menulis beberapa kitab seperti Mir'āh al-Tullāb, sebuah kitab yang membahas tentang jurisprudence atau hukum, Kifāyah al-Muhtajīn, karya yang lebih membicarakan tentang persoalan tasawuf, begitu juga kitab Daqāiq al-Hurūf, yang lebih berisi tentang syair Sufistik Ibnu 'Arabi. ${ }^{14}$ Adapun terkait dengan kitab tafsir Tarjumān al-Mustafid, Islah Gusmian menyimpulkan bahwa tidak ada keterangan pasti dari apakah kitab ini merupakan bagian dari perintah dari Sultānah atau tidak. Akan tetapi ia berasumsi bahwa kelahiran kitab ini tidak bisa lepas dari tujuan dan kepentingan tertentu, yakni guna mempermudah orang awam yang tak memahami bahasa Arab. Selain itu juga belum ada tafsir alQur'an berbahasa melayu secara lengkap. ${ }^{15}$

Syeh Nuruddin al-Raniri (penganut paham Syuhudiyah). Lihat juga Rizem Aizid, Biografi Ulama' Nusantara, 92.

12 Damanhuri, “'Umdatul Muhtajin: Rujukan Tarekat Syattariah Nusantara,” 310.

13 Arivaie Rahman, "Tafsir Tarjumān al-Mustafid Karya 'Abd al-Ra' ūf Al-Fansyuri: Diskursus Biografi, Kontestasi Politis-Teologis, dan Metodologi Tafsir,” Miqat 42, no. 1 (2018): 8 .

14 Salman Harun, "Hakekat Tafsir Tarjumān al-Mustafíd Karya Syekh Abdurrauf Singkel” (IAIN Syarif Hidayatullah, 1988), 27-30.

${ }^{15}$ Islah Gusmian, Khazanah Tafsir Indonesia (Yogyakarta: LKIS, 2013), 24. Salah satu kitab 'Abd al-Ra'üf yang penting untuk dicatat di sini adalah Sullām al-Mustafidìn, sebuah kitab yang berisi tentang pandangan teologisnya yang berlandaskan ahl al-sunnah wa al-jamä'ah. Karya ini juga menjadi penting di tengah perdebatan antara Hamzah Fansuri dan Nuruddin alRaniri tentang wujudiyah di Aceh pada abad ke-17. Lihat Nur Rahmah, "Sullam al-Mustafidin: The Theological Discourse in Aceh in 17 Century," Heritage of Nusantara: International Journal of Religious Literature and Heritage 7, no. 2 (2008). 
Setelah Sulțānah Safî’ah meninggal, ia kemudian digantikan oleh Sulțānah lain yang keturunannya sebenarnya belum jelas. Ia adalah Sri Sultan Nūr al'Alām Nakiyyah al-Dīn Syah (1675-1678 M), yang hanya memerintah sekitar tiga tahun. Di masa ini pula, masjid Bait al-Rahmān dan istana sultan hangus karena kebakaran. Setelah Sri Sultan meninggal, kepemimpinan Aceh dilanjutkan oleh Sultāanah yang lainnnya, yakni Sultan Ināyah Syah Zakiyyah alDīn yang memimpin dari tahun 1678-1688. Di masa inilah Sultan Ināyah meminta 'Abd al-Ra'ūf untuk menulis setidaknya dua karya yang diberi judul Risalat Adab Murid Akan Syaikh yang berisi tentang kewajiban menghormati antara seorang guru dan murid, dan sebuah syarh terhadap kitab hadis Arba'in al-Nawāwì. Selanjutnya, Sulțānah keempat sekaligus Sulțānah yang terakhir, Kamalah Syah, memimpin dari tahun 1688 sampai ia kemudian dicopot dari jabatannya pada tahun 1699. Penggulingan kepemimpinannya ini ditengarai oleh desakan pihak oposisi yang begitu kuat. Ada riwayat yang menyebutkan bahwa mufti saat itu -yang mendukung oposisi- akhirnya meminta fatwa kepada Mufti Besar Makkah untuk melegitimasi bahwa perempuan itu tidak layak untuk menjadi kepala negara. Kejatuhan Kalamat Syah tidak lepas juga tidak lepas dari fakta wafatnya 'Abd al-Ra'ūf pada tahun 1693 -dimana di masa SulțānahSultānah sebelumnya sampai dengan kepemimpinan Kalamat Syah selalu memberikan dukungan. ${ }^{16}$ Di sini bisa dilihat bagaimana pengaruh 'Abd al-Ra' ûf sangat kuat. Terlebih, ia juga menjadi mufti yang mempunyai pandangan yang cukup maju karena membolehkan perempuan menjadi Sulțānah.

Latar belakang sosio-religious seperti itulah yang menandari alur kehidupan 'Abd al-Ra'ūf. Ia hidup di masa dimana Iskandar Muda membuat Islam menjadi agama popular di Aceh. Salah satu bentuk kemajuan Islam waktu itu bisa dibuktikan dengan didirikannya masjid monumental yang diberi nama Masjid Bait al-Rahmān. ${ }^{17}$ Terlebih, salah satu arsip Turki menyebutkan bahwa ketika itu banyak masyarakat Aceh yang berbondong-bondong menunaikan ibadah haji ke Makkah. ${ }^{18}$

Adapun konteks politik di masa itu menunjukkan bahwa 'Abd al-Ra'ūf termasuk orang yang beruntung karena ia lahir pada masa saat kesultanan Aceh

${ }^{16}$ Dedeh Nur Hamidah, "Kepemimpinan Para Perempuan Muslim dari Kerajaan Aceh Darussalah," Tamaddun 5, no. 1 (2017): 76.

${ }^{17}$ Meskipun pada tahun-tahun berikutnya terjadi kebakaran, sebagaimana disinggung sebelumnya.

${ }^{18}$ Peter Riddel, “Abd Rouf Sinkili's Tarjuman al-Quran, Quran (A Critical Study of His Treatment of Juz 16)” (ANU Australia, 1984), 14. 
berada dalam masa keemasannya (1607). Meskipun pada akirnya sekitar tahun 1912 ke atas, Aceh mulai diserang oleh imperium-imperium dari luar. ${ }^{19}$

Dari latar belakang sosio-politik yang mendukung, dibarengi dengan kecerdasan dan kealiman 'Abd al-Ra'ūf, maka tidak mengherankan jika ia mempu menuliskan beberapa kitab yang menjadi pegangan rakyat Aceh. Diantaranya -selain yang telah disebutkan di atas- adalah 21 kitab yang terdiri dari 1 kitab tafsir yang berjudul Tarjumān al-Mustafid, 2 kitab hadis, 3 kitab fikih, serta selebihnya kitab tasawuf. ${ }^{20}$ Namun demikian, tidak dapat dipastikan jumlah kitab yang dikarang oleh 'Abd al-Ra'ūf. Azra, mengutip pendapat Hasjimi dan Voorhoeve, mengatakan ada 22 karya 'Abd al-Ra'ūf. Sedangkan Oman Fathurrahman mengatakan bahwa karya 'Abd al-Ra' ūf tidak kurang dari 36 kitab. $^{21}$ Selanjutnya, penulis akan memfokuskan pembahasan pada kitab Tafsir Tarjumān al-Mustafìd beserta beberapa penafsirannya.

\section{Tafsir Tarjumān al-Mustafìd: Sumber, Metode dan Corak}

\section{Sumber}

Kitab Tarjumān al-Mustafìd adalah kitab berbahasa Arab-Melayu ${ }^{22}$ lengkap 30 juz hingga surah terakhir pada abad ke $17 .{ }^{23}$ Karyanya tersebut merupakan kitab tafsir pertama berbahasa Melayu. Karyanya ini memiliki pengaruh yang sangat luas, dan pernah diterbitkan di beragam wilayah, seperti Istanbul, Singapura, Pulau Pinang serta Jakarta. Malahan, kitabnya tersebut sempat ditemui di pemukiman komunitas Melayu yang tinggal Afrika Selatan. ${ }^{24}$ Sebenarnya ia tak menulis sendiri kitabnya, muridnya bernama Dawud Rumi juga memiliki keikutsertaan dalam menambahkan kisah-kisah serta perbedaan qirā'ah meskipunn tetap atas persetujuannya. Para peneliti berpandangan jika

${ }^{19}$ Peter Gregory Riddel, “Abd Rouf Sinkili’s Tarjuman al-Quran (A Critical Study of His Treatment of Juz 16), 12.

${ }^{20}$ Tim Penyusun, Ensikopedi Islam, Vol. I (Jakarta: PT. Ichtiar Baru Van Hoove, 1997), 29.

${ }^{21}$ Arivaie Rahman, “Tafsir Tarjumān al-Mustafìd Karya 'Abd al-Ra'ūf Al-Fansyuri: Diskursus Biografi, Kontestasi Politis-Teologis, dan Metodologi Tafsir,” 6.

${ }^{22}$ Beberapa peneliti menggunakan istilah Melayu-Jawi atau Arab-Melayu. Namun bagi penulis keduanya sama saja, karena pada intinya tafsir karya 'Abd al-Ra'ūf memang menggunakan huruf Arab namun dengan cara baca Melayu. Dipakainya bahasa ini di waktu itu karena bahasa ini merupakan lingua-fanca yang dipakai Nusantara dan menjadi bahasa resmi yang dipakai pemerintahan, hubungan antar negara, dan perdagangan. Untuk lebih lengkapnya lihat Islah Gusmian, Khazanah Tafsir Indonesia, 51 .

${ }^{23}$ Rifa Roifa, dkk, "Perkembangan Tafsir di Indonesia (Pra Kemerdekaan 1900-1945)," al-Bayan: Jurnal Studi al-Quran dan Tafsir 2, no. 1 (2017): 22.

${ }^{24}$ Azyumardi Azra, Jaringan Ulama' Timur Tengah dan Kepulauan Nusantara abad XVII dan XVIII: Akar Pembaharuan Islam Indonesia (Jakarta: Kencana, 204), 245. 
kitabnya merupakan pengalihbahasaan dari Tafsīr al-Baiḍ̄wit. ${ }^{25}$ Namun Peter Riddel, Salman Harun, serta peneliti lainnya berpandangan jika karyanya tersebut merupakan hasil alihabahasa Tafsìr al-Jalālain, dengan menambahkan beberapa referensi Tafsīr al-Baid̄āwi ${ }^{26}$ Tafsìr al-Khāzin, dan berbagai kitab lain. ${ }^{27}$ Azyumardi Azra, lebih sependapat dengan yang kedua ini dengan alasan bahwa silsilah intlektual 'Abd al-Ra'üf memiliki keterhubungan dengan Jalal alDīn al-Suyuthi pengarang Tafsìr al-Jalālain, baik melalui al-Qușāși maupun alQurāni, sehingga besar kemungkinan 'Abd al-Ra' ûf lebih merujuk kepada Tafsīr al-Jalālain ketimbang tafsir lainnya. ${ }^{28}$

\section{Metode $^{29}$}

Bila melihat rujukan atau sumber yang dipakai oleh 'Abd al-Ra' ûf dalam tafsirnya, baik rujukan yang dipakai oleh al-Baid̄âwi dan al-Jalālain yang didominasi oleh al-ra'yi atau akal, maka Tarjumān al-Mustafìd termasuk tafsīr bi al-ra'yi, dengan metode ijmālī (global). Meskipun demikian, tafsir ini sangat kaya dengan berbagai pelengkap penafsiran seperti aspek qirā'ah, terutama mengutip tiga imam qirā'ah : qirā'ah Abū 'Amr riwayat Dūrī, qirā'ah Nāfī riwayat Qalun dan qirā'ah 'Āșim riwayat Hafs. Selain itu, dilengkapi pula dengan berbagai penafsiran para ulama' dari berbagai kitab tafsir: Tafsìr alBaid̄ōwī, Tafsìr al-Khāzin, Tafsìr al-Jalālain serta Tafsìr al-Śa'labī. Dan diperkaya dengan berbagai nukilan riwāyah asbāb al-nuzūl dan kisah umat terdahulu.

\section{Corak}

Apabila dilihat dari coraknya, tafsir ini coraknya general, sebab ia melingkupi beragam problem seperti kebahasaan, hukum Islam, tasawuf, filsafat, serta kemasyarakatan. Hal itu bisa dimengerti, sebab 'Abd al-Ra'ūf memiliki keahlian di beragam aspek keilmuan, seperti hukum Islam, tasawuf, filsafat, tauhid, sejarah, kebintangan, ilmu bumi, serta politik. Menariknya, meskipun 'Abd al-Ra'ūf juga penyebar dan mursyìd tarekat Syattariyah, namun nuansa penafsiran yang diberikan tidak terpengaruh pada satu bidang tertentu.

${ }^{25}$ Salah satu pengamat yang mengatakan demikian adalah Snouck Hurgronje. Bahkan Snouck mengatakan bahwa terjemahan ini merupakan terhemahan yang buruk dari tafsir Baidhowi. Lihat Salman Harun, Mutiara Al-Qur'an (Tarjumān al-Mustafìd: Tafsir Al-Qur'an Pertama di Indonesia) (Jakarta: Logos Wacana Ilmu, 1999), 198.

${ }^{26}$ Nama tafsirnya ialah Anwār al-Tanzīr wa Asrār al-Ta'wīl. Salah satu penafsiran yang merujuk pada tafsir ini ialah ketika 'Abd al-Ra'ūf menafsirakan surat al-Nās.

${ }^{27}$ Tim Penyusun, Ensikopedi Islam, Vol. I, 54.

${ }^{28}$ Azyumardi Azra, Jaringan Ulama' Timur Tengah dan Kepulauan Nusantara abad XVII dan XVIII: Akar Pembaharuan Islam Indonesia, 249.

${ }^{29}$ Metode penafsiran secara umum dibagi menjadi empat bagian: taḥlīlī, ijmāali, muqāran dan maudu' '. Lihat 'Abd al-Hay al-Farmāwī, al-Bidāyah fì al-Tafsīr al-Mauḍù 'i (Kairo: al-Hadarah al-Arabiyah, 1977), 37. 
Ini pun yang kemudian menjadi data penguat bahwa mereka yang menganggap bahwa tafsir ini merupakan tafsir sufi kurang tepat. ${ }^{30}$

\section{Beberapa Kata Kunci dalam Tafsir Tarjumān al-Mustafíd}

Dalam penelitian yang dilakukan oleh Arivaie, ${ }^{31}$ ia mengelompokkan beberapa kunci dalam tafsir Tarjumān yang mana seringkali diulang-ulang. Hal ini menunjukkan salah satu karakteristik dan model penyampaian 'Abd al-Ra'ūf kepada audiensnya saat itu. Di antara kata kunci tersebut ialah:

\section{Faidah (untuk menjelaskan perbedaan qirä'ah)}

Pada bagian awal tafsirnya, 'Abd al-Ra'ūf telah memberikan keterangan bahwa pembaca akan menemukan beragam bacaan qirā'ah di dalam tafsirnya, terutama tujuh qirā'ah yang masyhur beserta dua orang muridnya, yaitu 1. Nāfī, dua orang muridnya yakni: Qalun Warsy. 2. Ibn Kașīr, dua muridnya yakni: Bazzi serta Qunbul. 3. Abū 'Amr, dua muridnya yakni: Dūrī serta Susi. 4. Ibn 'Āmir, dua muridnya yakni Hasyim dan Żakwan. 5. 'Āṣim, dua muridnya yakni: Abū Bakr dan Hafs. 6. Hamzah, dua muridnya yakni: Khalāf dan Khalād. 7. Kisā'i, dua muridnya yakni: Abū Hariṭ dan Dūrī.

\section{Qișāh}

Kata ini menunjukkan dua pengertian. Pertama, kata ini digunakan untuk menjelaskan asbāb al-nuzūl, ini ditemui misalnya dalam 42 tempat ketika menafsirkan surat al-Fātiḥah dan al-Baqarah. Kedua, digunakan untuk menguraikan cerita atau kisah-kisah umat terdahulu.

\section{Tanbīh}

Kata kunci tanbīh (perhatian) misalnya hanya ditemukan satu kali dalam surat al-Baqarah, yakni pada surat ke 147 dan 148. "[tanbīh] barang siapa ada pahamnya akan maknanya al-haq min rabbika itu lain daripada maknanya tersebut".

Selain tiga kata kunci di atas, masih ada kata kunci lainnya semisal adapun, dan bermula, yakni dan lain sebagainya. Di mana kesemuanya memiliki karakter tersendiri dan tentunya 'Abd al-Ra'ūf memiliki maksud tertentu di dalamnya, apakah hanya sekedar mempermudah atau yang lainnya.

\section{Beberapa Penafsiran 'Abd al-Ra'ūf Singkel}

Berikut ini penulis mencoba untuk memberikan gambaran sekilas bagaimana penafsiran 'Abd al-Ra'ūf tentang beberapa isu yang sering kali dianggap krusial di masa modern-kontemporer. Diantaranya yakni tentang

30 Arivaie Rahman, "Tafsir Tarjumān al-Mustafìd karya 'Abd al-Ra'ūf al-Fansuri: Diskursus Biografi, Kontestasi Politis-Teologis, dan Metodologi Tafsir,” 13.

31 Arivaie Rahman, "Tafsir Tarjumān al-Mustafìd karya 'Abd al-Ra'ūf al-Fansuri: Diskursus Biografi, Kontestasi Politis-Teologis, dan Metodologi Tafsir,” 14-18. 
isrā'îliyah, pemimpin non-muslim dan peran laki-laki sebagai pemimpin perempuan. Hal ini perlu dikemukakan di samping karena melihat bagaimana corak atau model penafsiran dari 'Abd al-Ra'ūf, kita juga bisa mendapatkan gambaran apakah ia termasuk ulama' yang sudah maju di zamannya atau mengikuti alur pemikiran dan penafsiran yang sudah ada.

Adapun terkait dengan gambar asli dari kitab tafsirnya, penulis cantumkan di halaman-halaman akhir dari artikel ini.

\section{Tafsir Ayat-ayat Isrā'īliyah}

Salah satu kekurangan dari beberapa karya tafsir ulama terdahulu adalah adanya sumber-sumber isrá 'îliyah $h^{32}$ yang digunakan mereka dalam menafsirkan beberapa ayat al-Qur'an. Hal ini pun tidak luput dari tafsir Tarjumān al-Qur'ān. Padahal, Nabi Muhammad sendiri pernah mengatakan bahwa sumber-sumber isrā'iliyah itu tidak bisa dipastikan kebenaran maupun kesalahannya. Beliau berkata:

$$
\text { لا تصدقوا أهل الكتاب ولا تكذبوهم وقولوا أمنا بالله وما أنزل إلينا. (رواه البخاري)33 }
$$

Dan inilah yang kemudian dalam pandangan beberapa ulama kontemporer merupakan kekurangan dari karya tafsir terdahulu.

Bila kita melihat Tafsir Tarjumān al-Mustafìd, bisa dikatakan bahwa 'Abd alRa'ūf cukup banyak menggunakan sumber-sumber isrā' Diantaranya ketika ia menafsirkan kisah Jālut dan Mārut dalam surat al-Baqarah (2): 248 :

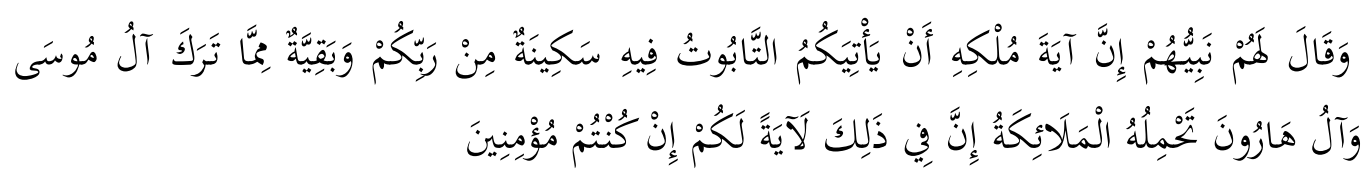

"Dan Nabi mereka mengucapkan kepada mereka: "Bahwasanya indikasi ia akan menjadi raja, ialah kembalinya tabut kepadamu, di dalamnya terdapat ketenangan ${ }^{34}$ dari Tuhanmu dan sisa dari peninggalan keluarga

${ }^{32}$ Isrā 'ìliyah merupakan kisah-kisah kenabian, umat terdahulu, dan lainnya. yang mana telah dijelaskan dalam kitab Taurat dan Injil secara rinci namun hanya disebutkan al-Qur'an secara umum. Nabi sendiri telah memberikan nasehat terkait dengan kisah-kisah isrā '̄iliyah yang dibawa oleh sahabat yang dulunya beragama Yahudi dan Nasrani. Adapun sahabat yang paling banyak menceritakan kisah isrā' ̄̄liyah. Lihat Mannā' al-Qaț̣ān, Mabāhịis fì 'Ulūm al-Qur'ān (Kairo: Maktabah Wahbah, t.t), 344-345.

${ }^{33}$ Riwayat isrā'iliyah yang paling menjadi perhatian ulama-dalam hal ikhtilafnya adalah riwayat dari Ka'b al-akhbār. Lihat Mannā' al-Qaț̣ān, Mabāhisis fì 'Ulūm al-Qur'ān, 354

${ }^{34}$ Tabut ialah peti tempat menyimpan Taurat yang membawa ketenangan bagi mereka. 
Mūsā dan keluarga Hārun; tābut itu dibawa malaikat. Sesungguhnya pada yang demikian itu terdapat tanda bagimu, jika kamu orang yang beriman."

Ayat di atas ditafsirkan 'Abd al-Ra'ūf sebagai berikut:

"Dan telah berkata bagi mereka itu Nabi mereka itu tatkala dituntut mereka itu daripadanya tanda atas kerajaan Talut itu bahawasanya tanda kerajaannya bahawa didatangkan akan kamu suatu peti di dalamnya ketetapan bagi segala hati kamu daripada Tuhan kamu dan yang mati daripada peninggalan Mūsā dan Hārun pada hal menanggung akan dia segala malaikat."

Setelah itu, terdapat tanda (قصة), “tersebut di dalam khāzin adalah peti itu di dalamnya rupa segala Nabi yang diturunkan Allah (أي) yakni, atas Adam maka turun temurun hingga datang kepada Mūsā dan adalah mereka itu menuntut kemenangan pada Allah dengan berkah peti itu atas seteru mereka itu. Dan dihantarkan mereka itu peti itu di hadapan mereka itu maka tetap mereka itu kepadanya tatkala perang dan di taruh di dalamnya oleh mereka itu tanda kerajaan Talut maka ditanggung akan dioleh malaikat antara langit dan bumi padahal mereka itu milik kepadanya hingga dihantarakan malaikat akan peti itu pada Talut maka percayalah mereka itu akan kerajaan Talut, wa Allāh a 'lam. Bahwasanya pada yang demikian itu niscaya akan tanda kerajaan kamu jika kamu percaya. "35

Dari penjelasan penafsiran di atas, penulis menemukan beberapa hal: Pertama, 'Abd al-Ra'ūf merujuk cerita ini pada kitab Khāzin. Kedua, bahasa yang digunakan penafsir adalah bahasa melayu yang bila dibandingkan dengan bahasa Indonesia sekarang akan sangat berbeda. Semisal dari penafsiran di atas dapat diketahui bahwa terdapat banyak pengulangan kata "mereka itu". Ketiga, dalam mengungkapkan cerita isrā'illyah di atas, 'Abd al-Ra' ūf mengakhiri tulisannya dengan kata "wa Allāh a lam", yang secara tidak langsung menunjukkan kedaifannya sebagai manusia, dan karenanya cerita itu bisa diterima atau ditolak. Jadi 'Abd al-Ra' ūf sendiri meski menggunakan riwayat isrā' 'liyah di atas, akan tetapi ia tidak menerima begitu saja riwayat tersebut.

\section{Penafsiran tentang Pemimpin Non-Muslim}

Penulis sengaja ingin menelusuri bagaimana pandangan 'Abd al-Ra'ūf ketika menafsirkan ayat-ayat mengenai non-muslim. Ini didasari oleh kenyataan

35 'Abd al-Ra'ūf al-Sinkili, Tarjumān al-Mustafíd (Singapura: Mathba'ah Sulaiman Mar'i), 1951. Di dalam kitab ini tidak tercantumkan halaman maupun nomor ayat, sehingga dalam mencari ayat-ayat yang terkait penulis menggunakan bantuan al-Qur'an pojok. 
bahwa ketika itu masyarakat Nusantara, khususnya Aceh juga sedang menghadapi tantangan Kolonial. ${ }^{36}$

Tafsiran surat al-Mā'idah (5), 51:

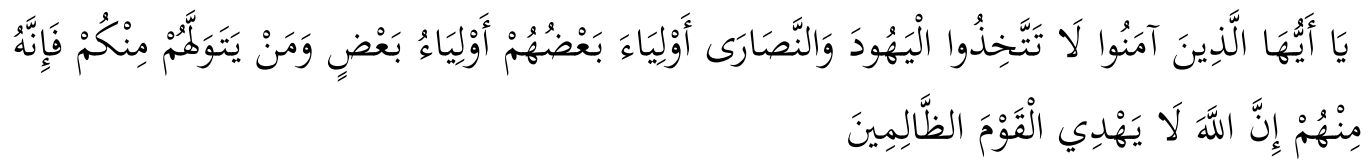

"Hai orang-orang yang beriman, janganlah kamu mengambil orangorang Yahudi dan Nasrani menjadi pemimpin-pemimpin(mu); sebahagian mereka adalah pemimpin bagi sebahagian yang lain. Barangsiapa diantara kamu mengambil mereka menjadi pemimpin, maka sesungguhnya orang itu termasuk golongan mereka. Sesungguhnya Allah tidak memberi petunjuk kepada orang-orang yang zalim."

Ayat di atas ditafsirkan oleh 'Abd al-Ra'ūf sebagai berikut:

"segala mereka yang percaya akan Allah jangan kamu ambil Yahudi dan Nasrani akan segala orang yang damping yang berkasih-kasihan. ${ }^{37}$ Mereka itu karena setengah mereka itu jua segala yang damping akan setengah mereka itu sebab bersatu mereka itu pada kufur. Dan barang siapa daripada kamu menjadikan mereka itu damping akan dibahwasanya adalah (أي yakni daripada jumlah mereka itu. Bahwasanya Allah tiada (أي) menanjaki ${ }^{38}$ segala kaum yang dholim dengan sebab berkasihkasihan dengan kufar itu. "39

Sekilas kita bisa lihat bahwa penafsiran 'Abd al-Ra' 'ûf terhadap kata auliyā' di atas adalah dengan makna damping atau pendamping. Ia tidak menggunakan kata pemimpin sebagai terjemahan. Jadi sejauh ini pemaknaan 'Abd al-Ra'ūf tidak seperti para ulama atau mufasir yang memaknai kata auliya ' sebagai pemimpin atau kepala negara.

${ }^{36}$ Lihat Tim Hannigan, A Brief History of Indonesia (t.k: Tuttle Publishing, 2015). Lihat juga beberapa negara yang pernah menjajah di Indonesia di https://www.idntimes.com/science/discovery/ineu-nursetiawati/negara-penjajah-indonesia-expc1c2/full.

${ }^{37}$ Di dalam tulisan tafsirnya tidak terdapat tanda titik, koma atau yang lainnya.

${ }^{38}$ Penulis masih ragu akan terjemahan kata ini.

39 'Abd al-Ra'ūf al-Sinkili, Tarjumān al-Mustafìd, 1951. 


\section{Penafsiran Laki-laki Sebagai Pemimpin Perempuan}

Penafsiran dan pemahaman ulama klasik akan laki-laki sebagai pemimpin perempuan tentu berbeda dengan penafsiran dan kenyataan sosial di era sekarang. 'Abd al-Ra'ūf pun memiliki pandangan tersendiri dalam hal ini. Misalnya ketika ia menafsirkan surat al-Nisā' (4): 34:

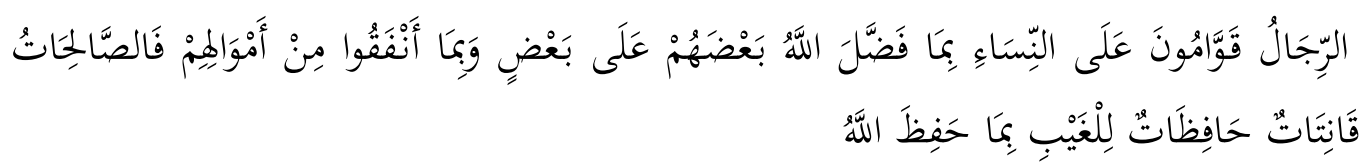

"Kaum laki-laki itu adalah pemimpin bagi kaum wanita, oleh karena Allah telah melebihkan sebahagian mereka (laki-laki) atas sebahagian yang lain (wanita), dan karena mereka (laki-laki) telah menafkahkan sebagian dari harta mereka. Sebab itu maka wanita yang saleh, ialah yang taat kepada Allah lagi memelihara diri ketika suaminya tidak ada, oleh karena Allah telah memelihara (mereka)."

Ayat di atas ditafsirkan oleh 'Abd al-Ra'ūf sebagai berikut:

"Bermula segala laki-laki itu dikarenakan mereka itu atas segala perempuan dengan sebab dilebihkan Allah segala laki-laki itu atas segala perempuan dengan ilmu dengan akal dan wilayah dan dengan sebab dibiyakan ${ }^{40}$ mereka itu atas mereka itu daripada segala arti mereka itu. Maka segala perempuan yang soleh itu berbuat bakti mereka itu akan segala suami mereka itu lagi memelihara mereka itu bagi segala farji mereka itu pada ketika ghoib segala suami mereka itu dengan sebab dipelihara akan akan Allah akan mereka itu. "41

Penafsiran 'Abd al-Ra'ūf di atas sekilas bisa dipahami bagaimana hegemoni kaum laki-laki yang masih menguasai dalam berbagai hal. Misalnya keilmuan, wilayah, dan lainnya. Ini tentu sangat berbeda dengan kenyataan sekang yang memperlihatkan bagaimana perempuan juga mampu bersaing dengan laki-laki dari berbagai bidang yang ada. Tentu membaca sebuah karya, dalam hal ini tafsir, harus dilihat juga latar belakang sosial dan sejarah yang melingkupinya. Karena dengan demikian, pembaca tidak akan terjebak pada pemaknaan yang parsial yang terkadang malah membuat sebuah tafsir tidak relevan lagi. Hal ini pula yang perlu diterapkan ketika seorang pembaca atau peneliti melihat karya Abd Rauf ini.

\footnotetext{
${ }^{40}$ Penulis ragu terhadap terjemahan kata ini

41 'Abd al-Ra'ūf al-Sinkili, Tarjumān al-Mustafìd, 1951.
} 


\section{- Gambar 1: Tentang Sumber Isrāầliyah}

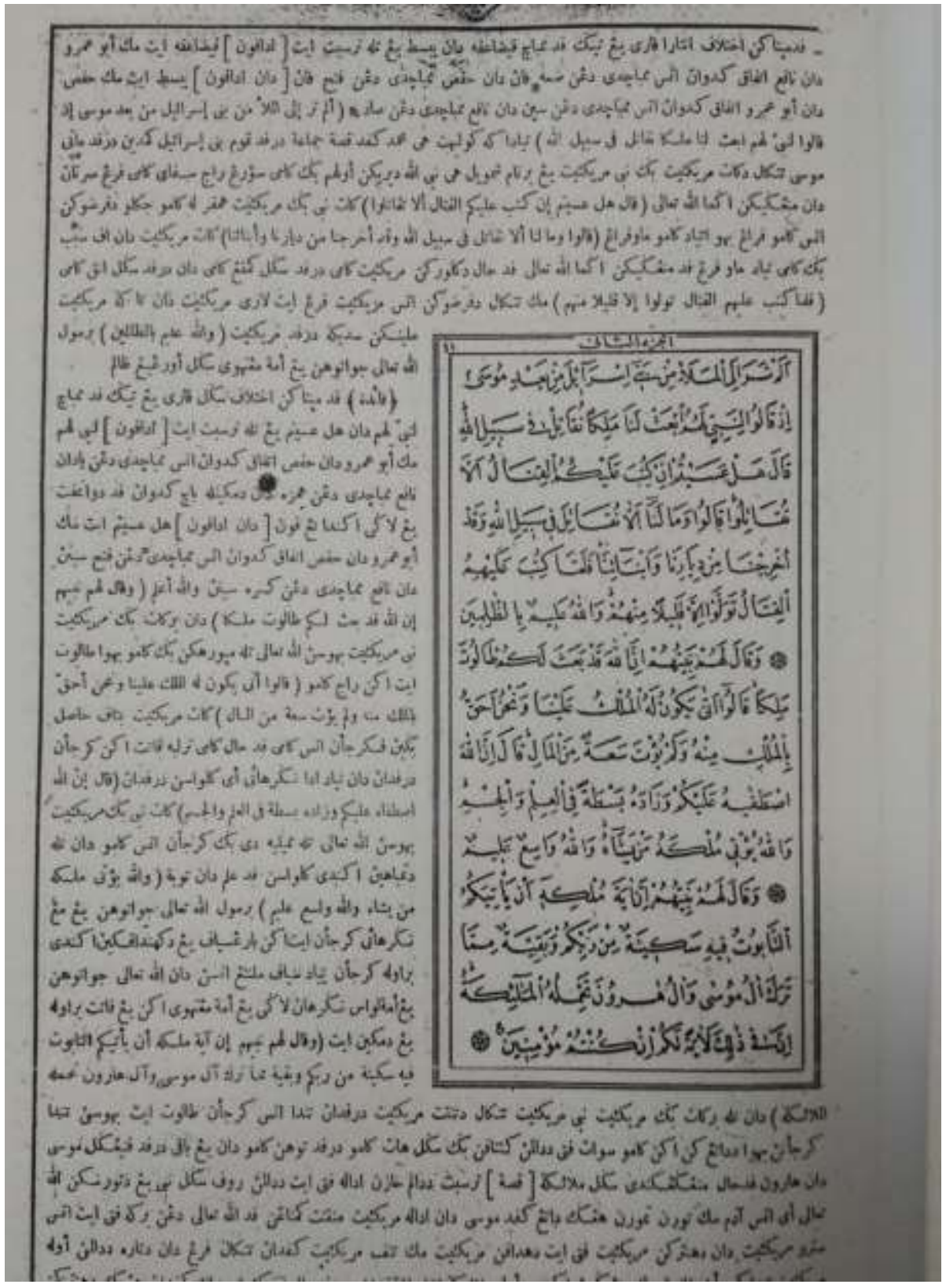




\section{- Gambar 2: Tentang Pemimpin Non-muslim:}

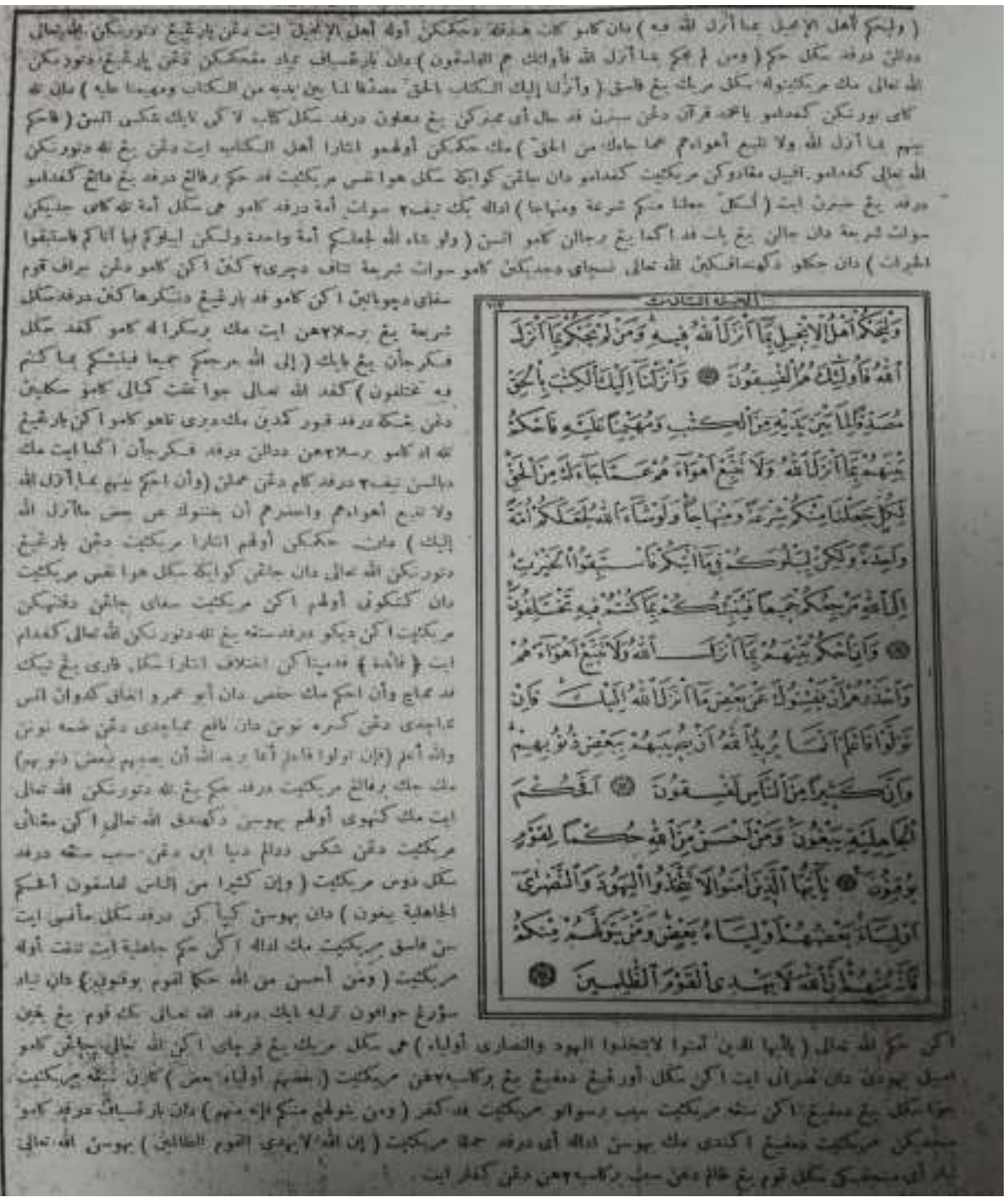


- Gambar 3: Tentang Laki-laki Pemimpin Perempuan:

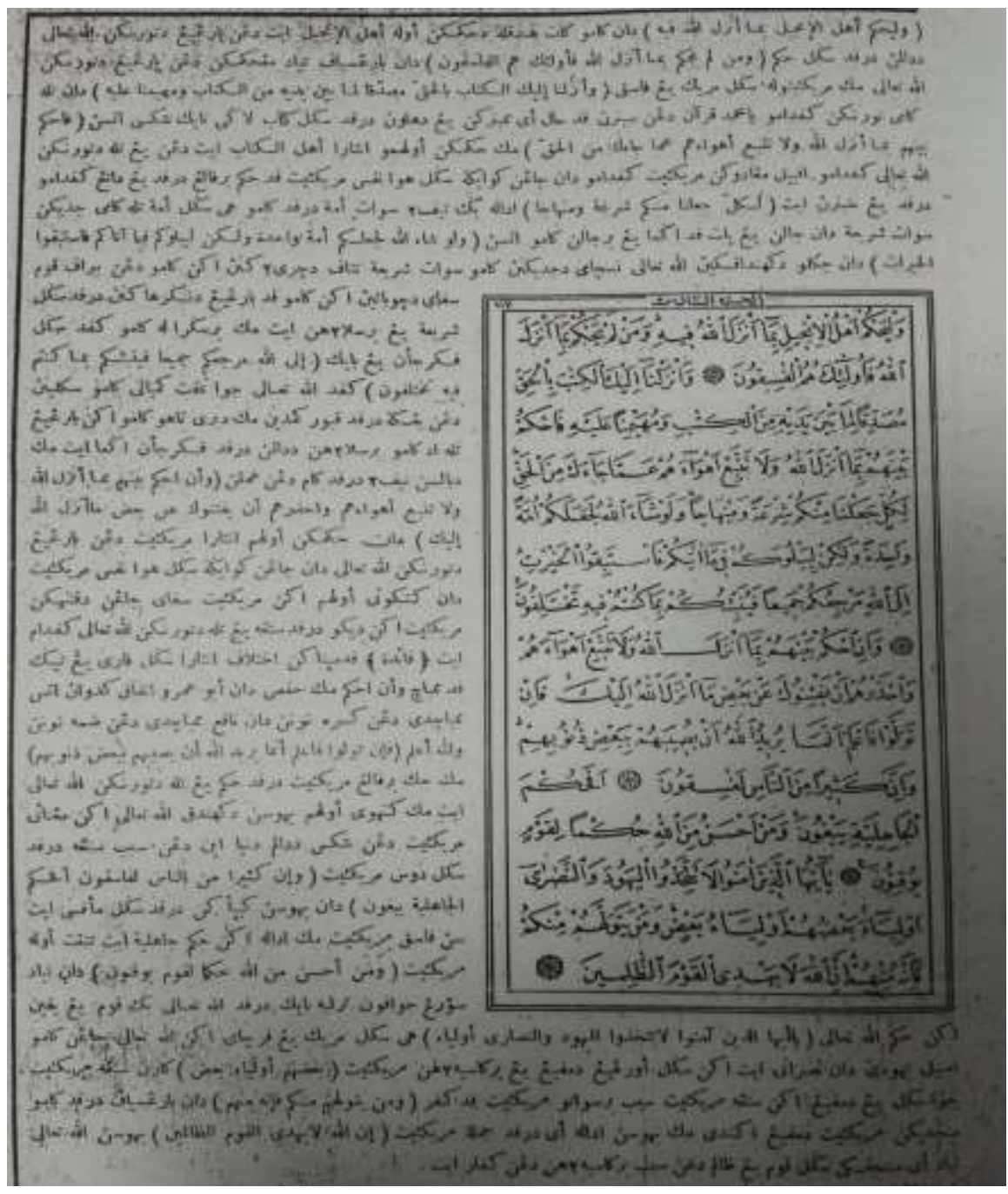

\section{Kesimpulan}

Kesimpulan yang bisa penulis utarakan adalah bahwa 'Abd al-Ra'üf Singkel merupakan sosok penting sekaligus pionir dalam menyebarkan Islam di abad ke-17, khususnya melalui karya tafsirnya yang merupakan terjemahan dari kitab tafsir al-Baid̄āwì. Sebegitu pentingnya posisi 'Abd al-Ra'ūf sehingga ia masuk dalam salah satu ulama penting dalam jaringan ulama Nusantara oleh Azyumardi Azra. 
Di sisi lain, bila sebagian pengamat menilai bahwa tafsir Tarjumān alMustafìd merupakan terjemahan dari tafsir Anwār al-Tanzīr wa Asrār al-Ta'wīl karya al-Baid̄āwì, perlu dicatat bahwa 'Abd al-Ra'ūf juga memberikan penafsiran-penafsirannya dalam beberapa hal. Terlebih, usaha yang dilakukannya di masa itu merupakan salah satu bentuk ijtihadnya dalam memahamkan masyarakat Nusantara akan Islam. Karena itulah tafsir ini sengaja dibuat dengan menggunakan tulisan Arab-Melayu.

Adapun terkait dengan beberapa penafsirannya yang telah penulis singgung di atas, 'Abd al-Ra'ūf masih mengikuti alur pemikiran dari ulamaulama di masanya, dalam arti bahwa penafsiran-penafsiran 'Abd al-Ra'ūf belum keluar dari "zona" di mana sekarang sering diperdebatkan. Hal ini dalam pandangan penulis dikarenakan sosio-kultural masyarakat Melayu waktu itu yang sangat mendukung akan gagasan-gagasan 'Abd al-Ra'üf, seperti pemimpin itu identik dengan laki-laki, dan lain sebagainya.

Terlepas dari itu semua, salah satu hal yang perlu dijadikan pelajaran dan diikuti oleh generasi di masa sekarang adalah bahwa 'Abd al-Ra' üf merupakan ulama yang sangat produktif dalam menulis, begitu juga dengan semangat belajarnya yang luar biasa.

\section{Daftar Pustaka}

Aini', Zulkefli, Che Zarrina Sa'ari, dan Mohamad Zulkifli Abdul Ghani. "Pendekatan Dakwah al-Wasatiyyah Syeikh Abdul Rauf Ali al-Fansuri (M.1693).” Afkar 20, no. 1 (2018).

Aizid, Rizem. Biografi Ulama Nusantara. Yogyakarta: Diva Press, 2016.

Akbarizan. Tasawuf Integratif Pemikiran dan Ajaran Tasawuf di Indonesia. Pekanbaru: Suska Press, 2008.

al-Farmāwī, Abd al-Hay. al-Bidāyah fì al-Tafsīr al-Mauḍu'i. Kairo: al-Hadarah al-Arabiyah, 1977.

Azra, Azzyumardi. The Origin of Islamic Reformism in SouthEast Asia (Network of Malay-Indonesian and Middle Eastern Ulama'in the Seventeenth and Eighteenth Century). Australia: University of Hawai's Press, 2004.

Baidan, Nashruddin. Perkembangan Tafsir al-Qur'an di Indonesia. Solo: Tiga Serangkai Pustaka Mandiri, 2003.

Damanhuri. "Umdatul Muhtajin: Rujukan Tarekat Syattariah Nusantara." Ulumuna: Jurnal Studi Keislaman 17, no. 2 (2013).

Gusmian, Islah. Khazanah Tafsir Indonesia. Yogyakarta: Elkis, 2013. Hannigan, Tim. A Brief History of Indonesia. t.k: Tuttle Publishing, 2015. 
Harun, Salman. Mutiara Al-Qur'an (Tarjumān al-Mustafid; Tafsir Al-Qur'an Pertama di Indonesia). Jakarta: Logos Wacana Ilmu, 1999.

Nur Hamidah, Dedeh. "Kepemimpinan Para Perempuan Muslim dari Kerajaan Aceh Darussalah." Tamaddun 5, no. 1 (2017).

Al-Qaț̣aān, Mannā'. Mabāḥis fì 'Ulūm al-Qur'ān. Kairo: Maktabah Wahbah, 1990.

Rahman, Arivaie. "Tafsir Tarjumān al-Mustafid karya 'Abd al-Ra' ūf al-Fansuri: Diskursus Biografi, Kontestasi Politis-Teologis, dan Metodologi Tafsir." Jurnal Miqot 42, no. 1 (2018).

Rahmah, Nur. "Sullam al-Mustafidin: The Theological Discourse in Aceh in 17 Century." Heritage of Nusantara: International Journal of Religious Literature and Heritage 7, no. 2 (2008).

Rasyad, dkk. "Tanbih Al-Masyi Al-Mansub Ila Thariq Al-Qusyasyi: Analisis Uslub Bahasa Arab dalam Karya "Abd Ar-Rauf As-Singkili sebagai Syaikh al-Islam dan Mufti Qadhi al-Adil di Kesultanan.” Adabiya 18, no. 35 (2016).

Riddel, Peter. “Abd Rouf Sinkili's Tarjuman al-Quran, Quran (A Critical Study of His Treatment of Juz 16)." (ANU Australia, 1984).

Roifa, Rifa dkk. "Perkembangan Tafsir di Indonesia (Pra Kemerdekaan 19001945)." al-Bayan: Jurnal Studi al-Quran dan Tafsir 2, no. (2017).

Roifa, Rifa, dkk. "Perkembangan Tafsir di Indonesia (Pra Kemerdekaan 19001945)." al-Bayan: Jurnal Studi al-Quran dan Tafsir 2, no 1 (2017).

Sholihin. Melacak Pemikiran Tasawuf Dinusantara. Jakatra: PT Raja Grafindo Persada, 2005.

Al-Sinkili, 'Abd al-Ra'üf. Tarjumān al-Mustafìd. Singapura: Mathba'ah Sulaiman Mar'i, 1951.

Taufiqurrahman. "Kajian Tafsir Indonesia." Jurnal Mutawâtir 2, no.1 (2012).

Tim Penyusun. Ensikopedi Islam. Jakarta: PT. Ichtiar Baru Van Hoove, 1997. 